\title{
STATUS PEMULIHAN STOK TERIPANG DI PERAIRAN KEPULAUAN SERIBU
}

\section{RECOVERY STATUS OF SEA CUCUMBER IN THE SERIBU ISLANDS}

\author{
Sri Turni Hartati'1), Didik Wahju Hendrotjahjo ${ }^{2)}$, \& Andrias S. Samusamu ${ }^{1)}$ \\ ${ }^{1)}$ Peneliti pada Pusat Riset Perikanan \\ ${ }^{2)}$ Peneliti pada Balai Riset Pemulihan Sumber Daya Ikan \\ e-mail : buce.prpt@gmail.com
}

Diterima tanggal: 13 Desember 2019 ; diterima setelah perbaikan: 29 Juni 2020; Disetujui tanggal: 29 Juni 2020

\begin{abstract}
ABSTRAK
Penelitian pemulihan stok teripang pasir (Holothuria scabra) telah dilakukann di Perairan Kepulauan Seribu pada dua periode yaitu tahun 2003 - 2004 dan tahun 2008-2009. Teripang yang digunakan dalam penelitian berasal dari perairan Ringgung, Teluk Lampung, ada yang berukuran benih maupun siap dilepaskan di alam. Teripang yang berukuran benih atau kurang dari 100 gram dibesarkan dahulu dalam kurungan tancap berlidah sampai berukuran matang gonad, panjang $220 \mathrm{ml}$ dan berat 200 - 300 gram. Pengamatan kondisi lingkungan perairan menunjukkan bahwa Pulau Kongsi mendukung untuk lokasi pembesaran teripang pasir (Holothuria scabra), dan Pulau Pamegaran sebagai lokasi untuk pelepasan teripang di alam (Restocking). Selain mempunyai habitat sesuai dengan habitat alami, perairan Pulau Pamegaran merupakan wilayah yang semi tertutup, dan sedimen dasar perairan relatif lebih halus. Jaring tancap berlidah merupakan sarana yang paling tepat untuk pembesaran teripang sebelum dilepas di alam, karena mempunyai tingkat kelolosan yang rendah bahkan dalam penelitian tingkat kelolosan dari jaring 0\%. Laju pertumbuhan teripang per hari pada beberapa kali percobaan pembesaran di Pulau Kongsi selama 8-9 bulan pada kisaran 0,41-0,82\% dengan kelolos hidupan mencapai $100 \%$. Laju pertumbuahan per hari teripang yang dilepas di perairan Pulau Pamegaran selama 12 bulan adalah 0,4\%, dengan tingkat kelolos hidupan 4\%. Melalui kegiatan pelepasan (restocking) teripang pasir, perairan Pulau Pamegaran dapat dimanfaatan sebagai daerah reservasi.
\end{abstract}

Kata Kunci : Pemulihan stok, Teripang pasir, Holothuria scabra, Kepulauan Seribu.

\section{ABSTRACT}

Research on the recovery of sand sea cucumber stock (Holothuria scabra) has been carried out in the Seribu Islands Waters in two periods, scilicet 2003 - 2004 and 2008-2009. Sea cucumbers used in the study came from the waters of Rended, Lampung Bay, some were seed-sized or ready too be released in nature. Sea cucumbers that have seed size or less than 100 grams are raised first in a tongue cage net to mature gonad size, $220 \mathrm{ml}$ in length and weight 200 - 300 grams. Observation of the condition of the aquatic environment shows that Kongsi Island supports the location for enlarged sand sea cucumbers (Holothuria scabra), and Pamegaran Island as locations for the release of sea cucumbers in nature (Restocking). Aside from having a habitat that is suitable for natural habitat, Pamegaran Island is a semi-enclosed area, and waters sedimentary are relatively fine sand. Tongue cage nets are the most appropriate means for sea cucumber enlargement before being released in nature, because they have a low escape rate even in studies of a $0 \%$ breakout rate. The growth rate of sea cucumbers per day on several attempts of enlargement on Kongsi Island for 8-9 months in the range of 0.41 to $0.82 \%$ with a survival rate of $100 \%$. The rate of growth per day of sea cucumbers released in the waters of Pamegaran Island for 12 months is $0.4 \%$, with a survival rate of $4 \%$. Through sea cucumber restocking activities, Pamegaran Island waters can be utilized as a reservation area.

Keywords: Stock recovery, Sea cucumbers, Holothuria scabra, Seribu Islands. 


\section{PENDAHULUAN}

Sumber daya perikanan adalah merupakan hak milik bersama (common property). Hak milik atas sumber daya tersebut tidak jelas, sehingga pengelolaannya bersifat open access yang berarti siapa saja boleh keluar masuk untuk mengelolanya (Smith \& Hasanudin, 1985). Oleh karena itu sering terjadi tekanan sumber daya yang menyebabkan gejala lebih tangkap (over fishing).

Kegiatan penangkapan ikan dan biota laut lainnya masuk dalam penggolongan food gathering dan hunting, nelayan hanya mengambil dari alam atau bersifat ekstratif. Konsekuensi dari kegiatan ini adalah bahwa hasil yang diperoleh berada dalam ketidakpastian (uncertainly). Untuk itu keberadaan sistem manajemen yang bisa menjamin pengusahaan sumber daya berkelanjutan merupakan kebutuhan yang utama dan mendesak.

Indonesia dikenal sebagai salah satu negara penghasil teripang. Pasaran utama teripang Indonesia terutama adalah untuk memenuhi permintaan negara- negara di daratan Eropa, Jepang, Singapura, Malaysia dan Amerika. Hingga saat ini produk teripang Indonesia yang bernilai ekonomis penting hanya sekitar $15-20$ jenis saja (Nuraini et al., 1990; Darsono, 2004) dan tersebar pada wilayah perairan pantai yang cukup luas. Wilayah perairan Kepulauan Seribu dan sekitarnya merupakan salah satu daerah penyebaran teripang di Indonesai (Djamali et al., 1998), dan usaha perikanannya telah dimulai sejak tahun 1973 . Tingkat pengusahaannya sangat intensif, hasil tangkapan nelayan dapat mencapai 1000 ekor dalam satu hari (Azkab \& Hutomo, 1986). Akibat aktifitas penangkapan yang berlebihan tersebut, pada saat ini populasinya semakin menurun, bahkan untuk beberapa jenis yang bernilai ekonomis penting cenderung langka, seperti teripang pasir (Holothuria scabra) dan teripang nanas (Thelenota ananas). Menurut Teswara (1995) kepadatan teripang di perairan Kepulauan Seribu berkisar antara $0.147-0.341 \mathrm{ind} / \mathrm{m}^{2}$. Penelitian yang dilakukan 5 tahun berikutnya oleh Hartati et al. (2001) kepadatan teripang semakin menurun, yaitu hanya berkisar antara $0,016-0,189 \mathrm{ind} / \mathrm{m}^{2}$. COP 14 CITES di Belanda pada Juni 2007, teripang (sea cucumber) termasuk salah satu komoditi yang dibahas (Anonim, 2007).

Teripang termasuk komoditas perikanan yang bernilai ekonomis cukup tinggi. Produk teripang digemari oleh kalangan etnis Cina dan sudah lama menjadi salah satu komoditas internasional (Eys, 1986; Aziz, 1987). Teripang mempunyai kandungan nutrisi yang sangat tinggi. Menurut Martoyo et al. (1994) teripang kering mengandung protein sebesar $82 \%$; karbohidrat $4,8 \%$ dan lemak hanya sebesar $1,7 \%$. Teripang juga dikenal sebagai bahan baku industri farmasi karena pada dinding badan teripang mengandung senyawa anti bakteri (holotoksin) yang berfungsi sebagai penghambat aktifitas bakteri (Shimada dalam Hashimoto, 1979).

Pengkayaan stok (stock enhancement) adalah satu upaya memulihkan atau meningkatkan ketersediaan sumber daya teripang yaitu dengan cara melepaskan benih pada suatu wilayah tertentu yang dianggap sesuai dengan kondisi habitat dari benih tersebut secara alami. Tulisan ini disusun dari hasil kegiatan penelitian pemulihan stok teripang pasir (Holothuria scabra) di perairan Kepulauan Seribu selama 2 periode yaitu 2003-2004 dan 2008-2010.

\section{BAHAN DAN METODE}

Jenis teripang yang digunakan untuk penelitian adalah teripang pasir (Holothuria scabra), berasal dari perairan Teluk Lampung. Pengambilan teripang dilakukan pada beberapa periode, yaitu 2003, 2004, 2008, dan 2009. Teripang yang berukuran benih sebelum di tebar dibesarkan dahulu dalam kurungan tancap/ kurungan pagar (pen culture). Benih teripang dibesarkan sampai berukuran matang gonad. Menurut Hartati et al. (2000), $22 \%$ teripang yang dibesarkan dalam kurungan tancap dalam kondisi matang telur pada berat antara 240 - 330 gram. Selain pembesaran benih juga dilakukan pelepasan (restocking) teripang yang berukuran kurang lebih dari 300 gram per ekor dan panjang $220 \mathrm{ml}$ dengan jumlah yang bervariasi pada setiap penebaran.

Penetapan lokasi pembesaran dan pelepasan teripang di alam berdasaran pengamatan kondisi lingkungan perairan yang sesuai dengan habitatnya di alam dan bersifat semi tertutup untuk lokasi penebaran. Parameter lingkungan perairan yang diamati meliputi kedalaman, kecerahan, suhu, salinitas, $\mathrm{pH}$, oksigen terlarut, kelimpahan plankton, dan sedimen.

Pengamatan pada saat pembesaran dan pasca pelepasan teripang di alam meliputi kondisi lingkungan perairan, perkembanganhan berat teripang untuk menghitung laju pertumbuhan dan jumlah yang tertangkap kembali untuk menghitung kelulusan hidup. Laju pertumbuhan yaitu berat yang dicapai dalam satu periode waktu tertentu dihubungkan dengan berat awal pada periode 
tertentu. (Buddemeier \& Kinzie (1976) dalam Supriharyono (2000) dengan rumus:

$G=\left[\left(\frac{W n}{W o}\right)^{1 / n}-1\right] x 100 \%$

dimana,

$\mathrm{G}=$ laju pertumbuhan per hari

$\mathrm{W}_{\mathrm{n}}=$ berat teripang pada hari ke $\mathrm{n}$

$\mathrm{W}_{\mathrm{o}}=$ berat awal teripang $(\mathrm{gr})$

$\mathrm{n}=$ umur (hari)

Kelulusan hidup (Survival Rate/ SR) dihitung dengan rumus:

$$
S R=\frac{N t}{N o} \times 100 \%
$$

dimana,

$\mathrm{SR}=$ Kelulusan hidup teripang $(\%)$

No $=$ Jumlah awal teripang (awal riset)

$\mathrm{Nt}=$ Jumlah teripang yang hidup (akhir riset).

\section{HASIL DAN PEMBAHASAN}

\section{Pemilihan Lokasi Penelitian}

Untuk menentukan lokasi pembesaran benih dan pelepasan teripang di alam dilakukan pengamatan kondisi lingkungan pada beberapa wilayah perairan (Tabel 1).
Hasil pengamatan menunjukkan bahwa pada semua stasiun pengamatan mempunyai kondisi lingkungan perairan yang sesuai dengan habitat teripang. Namun demikian stasiun 4 yang terletak di sebelah utara Pulau Pamegaran relatif lebih lebih tepat sebagai habitat teripang. Sedimen dasar perairan pada stasiun 4 relatif lebih halus (Tabel 2), sehingga ada kecenderungan kelimpahan detritus yang merupakan makanan utama teripang selain plankton relatif lebih tinggi. Demikian juga dengan predator dan kompetitor seperti penyu, ikan-ikan besar, kepiting, bulu babi, bintang laut dan triton relatif lebih sedikit ditemukan. Secara geografis wilayah perairan Pamegaran lebih terlindung atau tertutup dan banyak ditumbuhi lamun dan bakau. Stasiun 5 yang terletak di sebelah barat Pulau Kongsi ditetapkan sebagai lokasi untuk pembesaran benih, karena selain kondisi lingkungan perairannya memenuhi persyaratan untuk kehidupan teripang, juga adanya pertimbangan kemudahan dalam pengawasan.

\section{Pengadaan Sarana Pembesaran}

Program yang dijalankan pada pengkayaan stok di Jepang adalah pengadaan pembesaran bibit (intermediate culture) dan program pelepasan (restocking). Pada pengadaan pembesaran bibit tentunya dibutuhkan sarana yang tepat. Sarana pembesaran teripang pada umumnya berupa kurungan tancap atau kurungan pagar (pen culture).

Tabel 1. Kondisi lingkungan pada beberapa wilayah perairan di Kepulauan Seribu Mei 2003

\begin{tabular}{lllllllll}
\hline No & Parameter & \multicolumn{7}{c}{ Stasiun } \\
\hline & & 1 & 2 & 3 & 4 & 5 & 6 & 7 \\
1 & Kedalaman (m) & 19,5 & 5,1 & 0,75 & 4,75 & 1 & 13,97 & 4,82 \\
2 & Kecerahan (\%) & 71,8 & 100 & 100 & 60 & 100 & 60,84 & 100 \\
3 & Salinitas (o/oo) & 32 & 32,5 & 32 & 32,4 & 32,70 & 32 & 32 \\
4 & Suhu $\left({ }^{\circ} \mathrm{C}\right)$ & 30,5 & 30,3 & 31,46 & 30,85 & 31,60 & 30,41 & 30,40 \\
5 & Arus (m/s) & 0,15 & 0,06 & 0,4 & 0,03 & Ttd & 0,16 & 0,06 \\
6 & pH & 7,41 & 7,43 & 7,65 & 7,76 & 7,02 & 7,51 & 7,42 \\
7 & Fitoplankton $\left(\mathrm{sel} / \mathrm{m}^{3}\right)$ & $10^{5}$ & $10^{5}$ & $10^{4}$ & $10^{6}$ & $10^{4}$ & $10^{4}$ & $10^{4}$ \\
8 & Zooplankton $\left(\mathrm{ind} / \mathrm{m}^{3}\right)$ & $10^{3}$ & $10^{4}$ & $10^{4}$ & $10^{4}$ & $10^{3}$ & $10^{3}$ & $10^{3}$ \\
9 & Substrat & \multicolumn{7}{c}{ (Lihat Tabel 2) } \\
10 & Biologi & K, Pre & K, Pre & Kr, Pre K, L & K, L & K, Pre & K, Pre \\
& & L, Kom Kom,L & Kom,L & & Kom,L Kom,L \\
\hline
\end{tabular}

\section{Keterangan:}

Stasiun 1 Perairan Pulau Panjang Kecil 1 (053'31,1” S; 106 33’13,8” E)

Stasiun 2 Perairan Pulau Panjang Kecil 2 (053'31,1” S; 106 33’13,8” E)

Stasiun 3 Perairan Pulau Pamegaran 1 (053'01,7’' S; 106³4'18,5” E)

Stasiun 4 Perairan Pulau Pamegaran 2 (053'02,4” S; 106 34'41,3” E)

Stasiun 5 Perairan Pulau Kongsi (0551'20,6”' S; 106³5'54,1” E)

Stasiun 6 Pulau Kayu Angin Bira 1 (0536'26,9”' S; 106³3'56,6” E)

Stasiun 7 Pulau Kayu Angin Bira 2 (0536'24,9” S; 106³4'09,1” E).

K (karang), L (lamun), Pre (predator), Kom (kompetitor) 
Tabel 2. Persentase ukuran butiran substrat dasar perairan Pulau Pamegaran, Pulau kayu Angin Bira dan Pulau Panjang Kecil.

\begin{tabular}{|c|c|c|c|c|c|}
\hline No & $\begin{array}{l}\text { Diameter } \\
(\mathrm{mm})\end{array}$ & Kriteria & Pamegaran & $\begin{array}{l}\text { Kayu Angin } \\
\text { Bira }\end{array}$ & $\begin{array}{l}\text { Panjang } \\
\text { Kecil }\end{array}$ \\
\hline 1 & $>0,8$ & $\begin{array}{l}\text { Pasir sangat } \\
\text { kasar }\end{array}$ & 16 & 14 & 45 \\
\hline 2 & 0,7 & Pasir kasar & 2 & 3 & 5 \\
\hline 3 & 0,5 & Pasir & 9 & 19 & 17 \\
\hline 4 & 0,25 & Pasir halus & 24 & 53 & 25 \\
\hline 5 & 0,149 & Pasir halus & 21 & 8 & 5 \\
\hline 6 & 0,075 & $\begin{array}{l}\text { Pasir sangat } \\
\text { halus }\end{array}$ & 11 & 0 & 1 \\
\hline 7 & 0,053 & Lanau kasar & 2 & 0 & 0 \\
\hline \multirow[t]{2}{*}{8} & $<0,053$ & Lanau/ lempung & 15 & 3 & 2 \\
\hline & & Total & 100 & 100 & 100 \\
\hline
\end{tabular}

Teripang merupakan hewan yang hidup di dasar perairan dan pergerakannya relatif lambat. Meskipun gerakan teripang tergolong lambat, desain dan konstruksi kurungan pembesaran harus dapat menjamin teripang tidak lolos dari dasar perairan. Kurungan tancap/pagar dari jaring mempunyai tingkat kelolosan teripang kecil, yaitu maksimum $10 \%$, sehingga kurungan tersebut yang biasa disebut jaring tancap berlidah dipergunakan dalam penelitian (Gambar1).

Bentuk dan ukuran jaring tancap berlidah bervariasi, yang dipergunakan dalam penelitian berbentuk empat persegi panjang atau bujur sangkar dengan ukuran $400 \mathrm{~m}^{2}(20 \mathrm{~m}$ x 20m). Pancang kayu/bambu ditancapkan ke dasar perairan sesuai dengan bentuk dan ukuran kurungan pagar yang kita kehendaki. Jarak antar pancang berkisar antara 1-2 m, sedangkan tinggi pancang dasar perairan $150-200 \mathrm{~cm}$. Jaring dari bahan polietilen dengan lebar mata $0,5-1$ in direntangkan pada pancang kayu yang telah dipasang di lokasi pembesaran. Bagian jaring yang berada di dasar perairan diikatkan pada sebilah papan dan dibenamkan
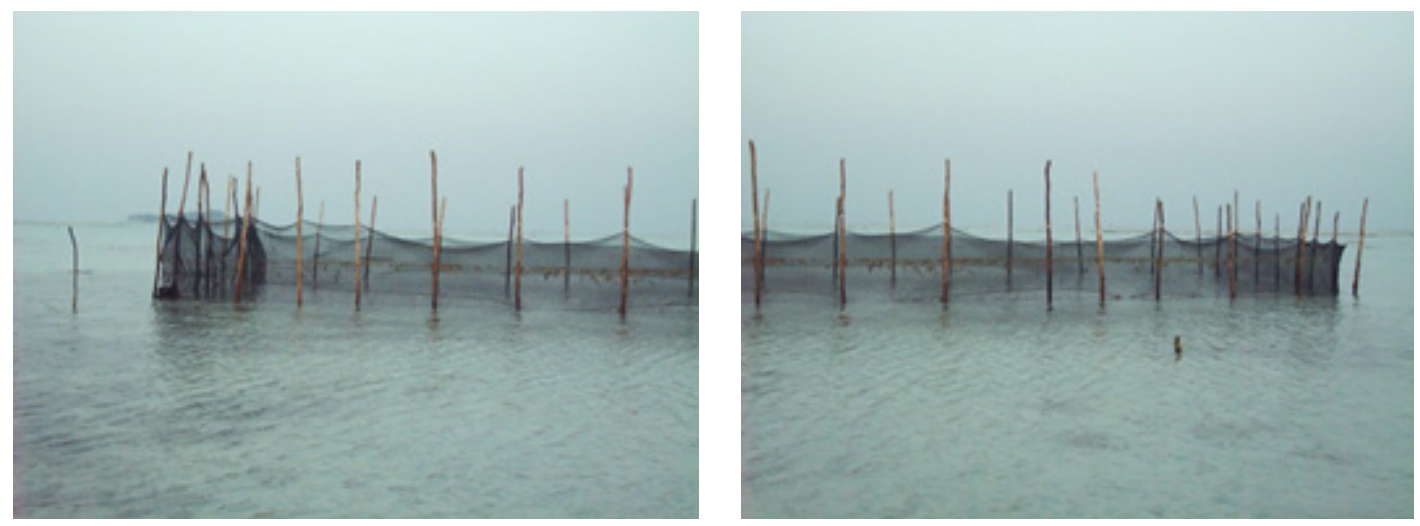

Gambar 1. Kurungan tancap berlidah sebagai sarana intermediate culture di perairan barat Pulau Kongsi. di dasar perairan agar teripang tidak meloloskan diri. Jaring bagian atas diberi tali ris dari bahan polietilen berdiameter $0,6-0,8 \mathrm{~cm}$ agar kuat dan terbuka mata jaringnya.

\section{Pengadaan teripang, pelaksanaan pembesaran, dan pelepasan}

Teripang diperoleh dari perairan Ringgung, Teluk Lampung dan dikemas dalam kantong plastik yang berisi air dan oksigen dengan perbandingan $1: 2$, setelah sehari sebelumnya dikosongkan isi perutnya (diberokan). Dalam 1 kantong berisi 20 - 50 individu, tergantung dari berat teripang yang mau dibawa Kemudian kantong dimasukkan dalam kotak sterofom dan diberi pendingin berupa es batu yang dibungkus dengan kertas koran untuk menjaga suhu tetap stabil (Gambar 2). Teripang diangkut lewat darat dan laut sampai ke Kepulauan Seribu selama kurang lebih 20 jam, dan kelolos hidupan (survival rate) mencapai $100 \%$. Setelah proses aklimatisasi kemudian teripang yang berukuran kurang dari 100 gram dibesarkan terlebih dahulu didalam kurungan tancap berlidah 
yang sudah disiapkan di perairan barat Pulau Kongsi (Gambar 3). Teripang yang berukuran kurang lebih sudah matang gonad langsung di lepas di perairan
Pulau Pamegaran (Gambar 4).
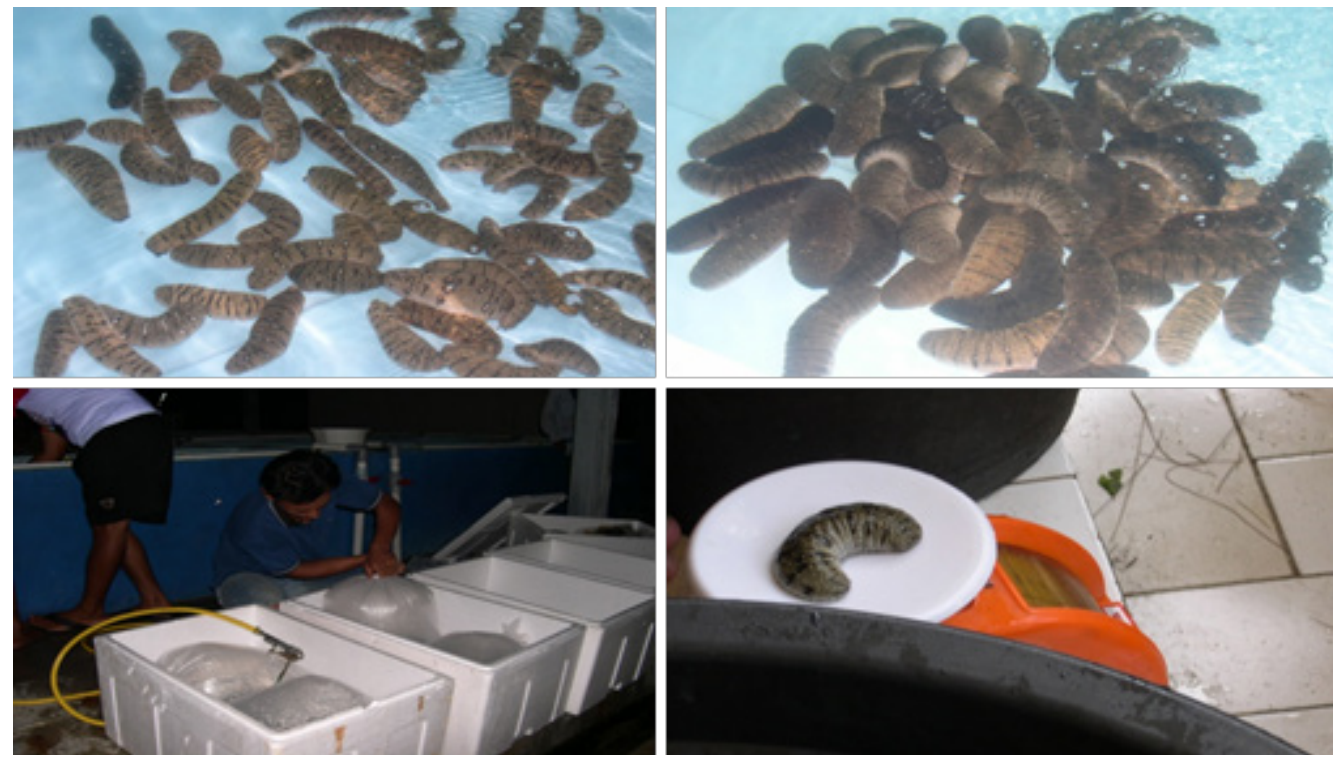

Gambar 2. Proses pengadaan teripang dari Perairan Ringgung, Teluk Lampung.
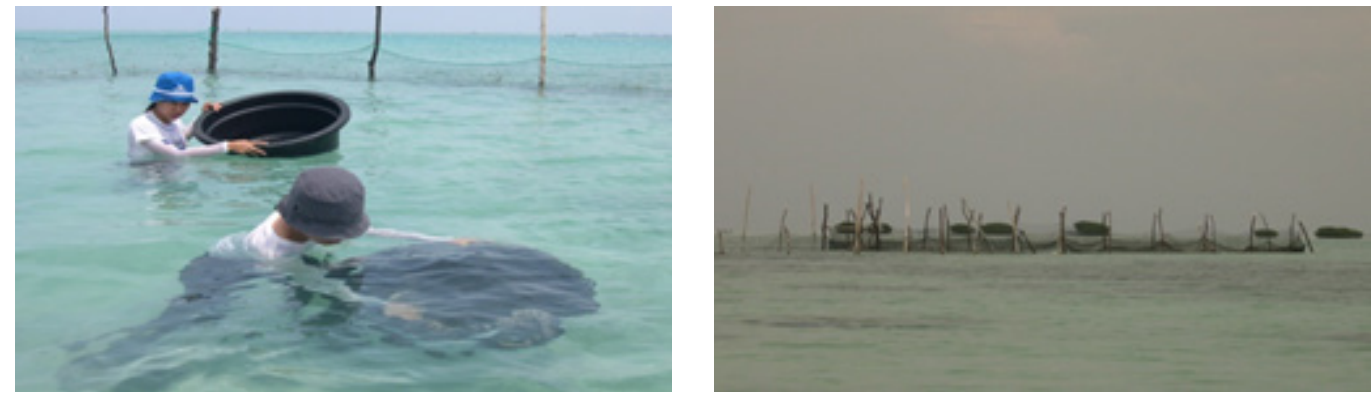

Gambar 3. Pelaksanaan pembesaran teripang di Pulau Kongsi bulan September 2003.
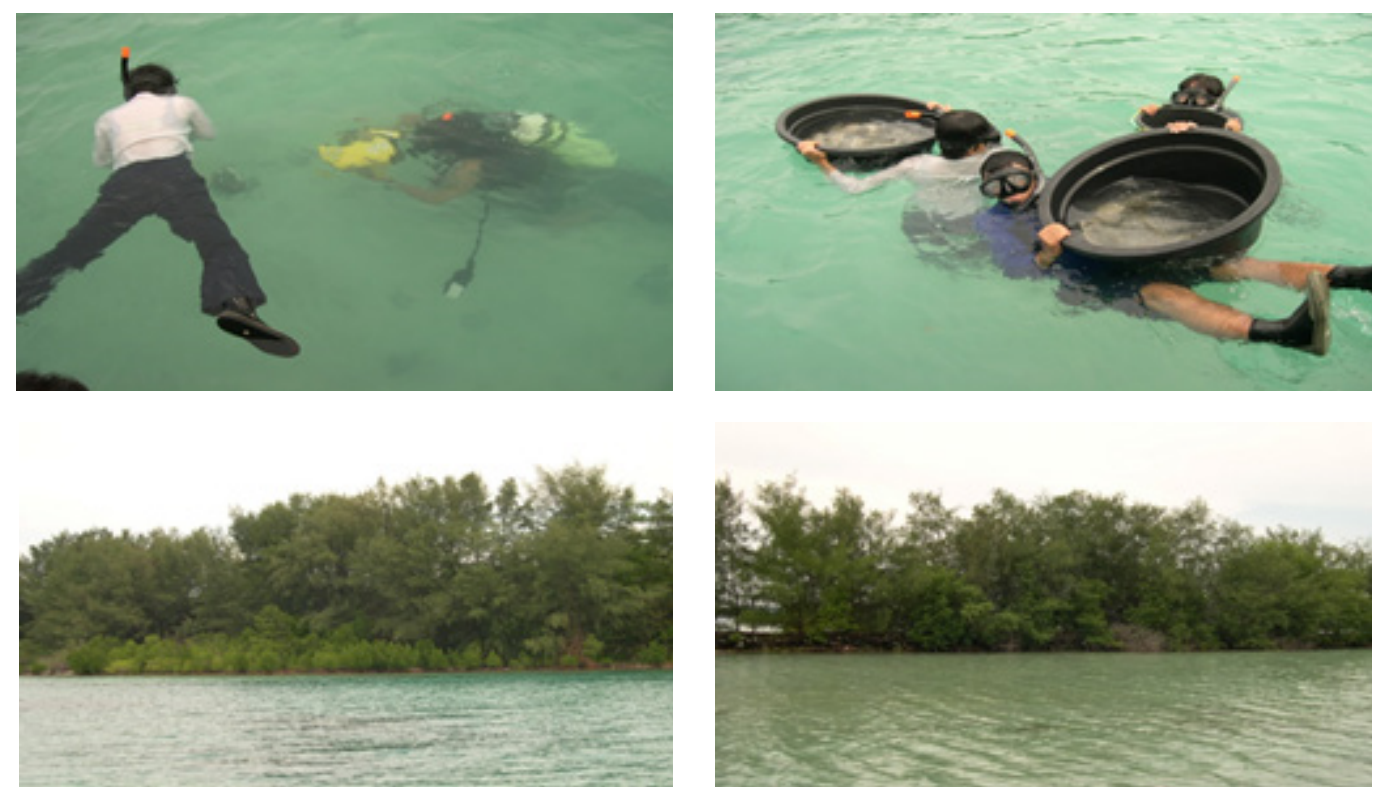

Gambar 4. Pelepasan teripang di perairan Pulau Pamegaran. 


\section{Laju Pertumbuahan dan Keloloshidupan}

Pertumbuhan teripang yang dibesarkan di perairan Pulau Kongsi dari rata-rata 51 gram/ekor pada bulan September 2003 menjadi 119 gram pada Oktober, 130 gram/ekor pada November 2003, dan 250 gram pada Mei 2004. Pembesaran teripang pada Mei - Desember 2004, mempunyai pola pertumbuhan yang berbeda, pertumbuhan sangat lambat pada Mei - September 2004 dari berat rata-rata 67 gram/ekor menjadi 74/ekor. Setelah dilakukan pemindahan posisi dari kurungan pembesaran pertumbuhan teripang menjadi lebih cepat. Kondisi ini kelihatannya adanya keterkaitannya dengan ketersediaan pakan. Pada pengamatan pada November 2004 berat teripang rata-rata menjadi 229 gram/ekor. Grafik pertumbuhan teripang yang dibesarkan di Pulau Kongsi pada tahun 2003-2004 disajikan pada Gambar 5.

Pembesaran teripang yang dilakukan pada 2008 -2009 mempunyai pola yang hampir sama, setelah mencapai berat 250 -300 gram/ekor, pertambahan berat sangat lambat. Kondisi ini menunjukkan bahwa pada area yang terbatas, ketersediaan makanan sangat mempengaruhi pertumbuhan teripang (Gambar 6).

Dengan demikian laju pertumbuhan teripang per hari pada beberapa kali percobaan pembesaran di Pulau Kongsi selama 8- 9 bulan pada kisaran kisaran 0,41$0,82 \%$ dengan kelolos hidupan mencapai $100 \%$. Pengamatan pada teripang yang dilepas di Pulau
Pamegaran pada September 2003 sebanyak 400 ekor dengan rata-rata berat 338,50 gram/ekor, pada bulan Oktober ditemukan kembali sebanyak 70 ekor atau $17,5 \%$ dengan rata-rata berat 468 gram/ekor, kemudian pada bulan Nopember 52 ekor atau $13 \%$ dengan ratarata berat 619,80 gram/ekor. Dengan demikian laju pertumbuhan per hari teripang yang ditebar di perairan Pulau Pamegaran selama 3 bulan adalah 1,013\%. Pergerakan teripang yang ditebar pada pengamatan bulan Oktober terjauh mencapai 61 meter dari titik awal ke arah barat daya, pada Nopember mencapai 198 meter ke arah selatan. Pergerakan teripang menuju ke perairan yang lebih dalam dengan substrat dasar perairan lebih halus atau pasir berlumpur (Gambar 5). Tabel 3 menunjukkan perkembangan teripang yang ditebar di perairan Pulau Pamegaran selama 3 bulan.

Selanjutnya pada pengamatan bulan Mei 2004 teripang yang ditebar pada bulan September 2003 berhasil tertangkap kembali 20 ind atau 5\%, dengan rerata berat 901,75 gr/ind (Gambar 7).

Pada pengamatan bulan Juni sampai Desember 2004, jumlah yang tertangkap kembali berfluktuatif (9 -36 ind), dengan kisaran rerata berat antara 932,2 - 1041,32 gr/ind (Tabel 4). Dari hasil pengamatan tersebut dapat diketahui bahwa laju pertumbuhan per hari teripang yang dibesarkan selama September 2003 - Desember 2004 di perairan Pulau Pamegaran adalah 0, $268 \%$. Teripang yang dilepas pada September 2003 masih
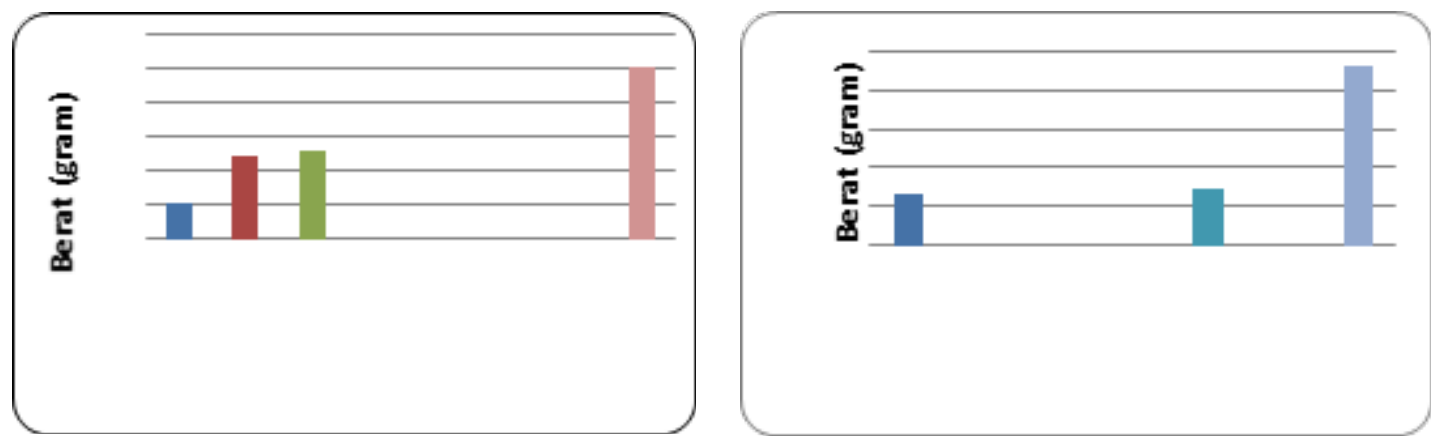

Gambar 5. Pertumbuhan teripang pasir dalam pembesaran padatahun 2003-2004.
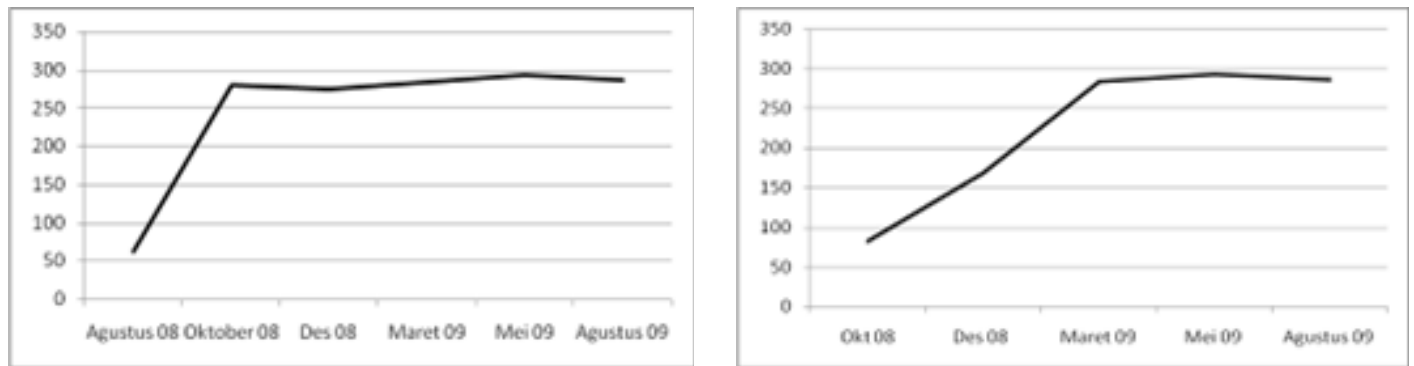

Gambar 6. Pertumbuhan teripang pasir dalam pembesaran padatahun 2008 - 2009. 
Tabel 3. Jumlah (ekor) dan rata-rata berat (gram) teripang yang dilepas serta hasil pemantauan pada bulan Oktober dan Nopember 2003

\begin{tabular}{llll}
\hline Uraian & $\begin{array}{l}\text { Awal pelepasan } \\
\text { (September 2003) }\end{array}$ & $\begin{array}{l}\text { Pengamatan 1 } \\
\text { (Oktober 2003) }\end{array}$ & $\begin{array}{l}\text { Pengamatan 2 } \\
\text { (November 2003) }\end{array}$ \\
\hline Total (ekor) & 400 & 70 & 52 \\
$\begin{array}{l}\text { Persentase } \\
\text { Rata-rata berat (gr) }\end{array}$ & 100 & 17,5 & 13 \\
Pergerakan (m) & 338.50 & 468.0 & 619.80 \\
& Awal (0) & 61 & 198 \\
\hline
\end{tabular}

dapat teramati pada bulan Oktober 2008, yaitu ditemukan sebanyak 16 ekor dengan rerata berat 1025 gram. Perkembangan pertumbuhan teripang yang dilepas pada bulan Mei 2009 disajikan pada Tabel 5. Teripang yang dilepas pada bulan Mei 2009 di perairan Pulau Pamegran sebanyak 400 ekor dengan rata-rata berat 293 gram/ekor. Pengamatan pada bulan Agustus dan Oktober 2009 tertangkap kembali sebanyak 149 dan 124 ekor dengan berat rata-rata 452 gram/ekor dan 543 gram/ekor. Laju pertumbuhan pada perhitungan bulan Agustus 2009 adalah 0,48\% dan pada bulan Oktober 2009 adalah 0,41\%.

Menurut hasil penelitian Hartati et al, 2000 , pada awal periode pengamatan nilai laju pertumbuhan teripang yang dilepas di alam relatif sama dengan teripang dalam kurungan pembesaran yaitu selama 6 bulan sebesar $1,01 \%$.

Pelepasan teripang juga dilakukan pada 2 wilayah perairan lain, yaitu goba Pulau Tikus pada bulan November 2003 dan di DPL Gosong Pramuka pada bulan Oktober 2008. Pelepasan teripang yang dilakukan pada bulan November 2003, pada pengamatan bulanbulan berikutnya tidak berhasil terpantau kembali. Kondisi tersebut disebabkan oleh 2 kemungkinan, yaitu teripang terbenam dalam dasar perairan sehingga tidak terlihat atau tertangkap oleh nelayan yang penangkapannya dengan cara diselam. Kondisi teripang pasca penebaran di DPL Gosong Pramuka relatif sama, yaitu hanya terpantau dengan persentase yang sangat rendah pada bulan Desember 2008, Maret 2009 dan Mei 2009 dan bahkan pada pengamatan bulan Agustus 2009 sudah tidak terpantau sama sekali. Pertumbuhan
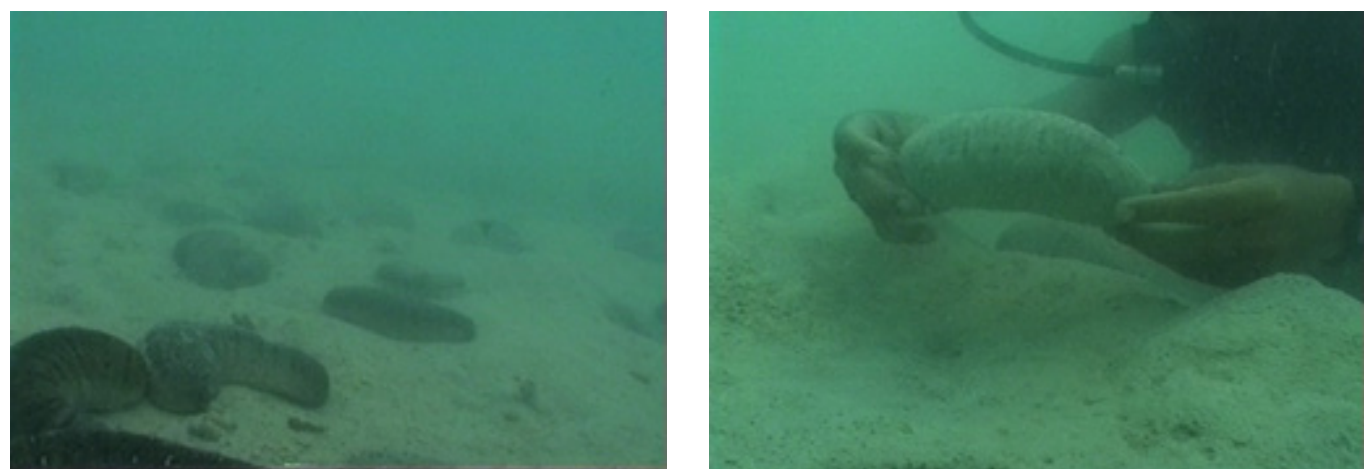

Gambar 7. Pengamatan teripang yang ditebar di perairan Pulau Pamegaran.

Tabel 4. Data perkembangan stok teripang pasca pelepasan bulan September 2003

\begin{tabular}{llclll}
\hline No & Bulan & Tertangkap $(\mathbf{N}) \%$ & $\mathbf{\%}$ & Rerata $(\mathbf{W})$ & Laju pertumbuhan \\
\hline 1 & Okt 2003 & 70 & 17,5 & 468,0 & 1,085 \\
2 & Nov 2003 & 52 & 13,0 & 619,80 & 1,013 \\
3 & Mei 2004 & 20 & 5 & 901,75 & 0,409 \\
4 & Juni 2004 & 9 & 2,25 & $1.011,0$ & 0,406 \\
5 & Agus 2004 & 22 & 5,5 & 936,36 & 0,309 \\
6 & Sept 2004 & 36 & 9,0 & 932,2 & 0,282 \\
7 & Des 2004 & 34 & 8,5 & $1.041,32$ & 0,268 \\
8 & Okt 2008 & 16 & 4 & 1.025 & - \\
\hline
\end{tabular}


Tabel 5. Data perkembangan stok teripang pasca pelepasan bulan Mei 2009.

\begin{tabular}{llllll}
\hline No & Bulan & Tertangkap (N) & \% & Rerata (W) & Laju pertumbuhan \\
\hline 1 & Agust 2009 & 149 & 37,25 & 452 & 0,48 \\
2 & Okt 2009 & 124 & 31,00 & 543 & 0,41 \\
\hline
\end{tabular}

teripang di DPL Gosong Pramuka relatif rendah, pada awal pelepasan di DPL Gosong Pramuka, rata-rata berat teripang 279 gram/individu, pada Maret 2009 hanya mencapai 284 gram/individu. Kondisi habitat di DPL Gosong Pramuka kurang mendukung, meskipun sebagai daerah perlindungan yang semula diharapkan dapat meminimalisir terjadinya penangkapan oleh masyarakat sekitar.

\section{Kondisi Lingkungan Perairan}

Hasil pengamatan kondisi lingkungan perairan Pulau

Pamegaran dari 8 kali pengamatan pada periode 2003 - Perairan Pulau Pamegaran yang dimanfaatkan untuk

Tabel 6. Data perkembangan stok teripang pasca pelepasan pada Mei 2009.

\begin{tabular}{|c|c|c|c|c|c|c|c|c|c|}
\hline No & Parameter & Sept'03 & Okt & Nov & Mei'04 & Jun & Agus & Sep & Des \\
\hline 1 & Kedal (m) & $1-4$ & - & - & - & - & - & - & - \\
\hline 2 & Kecer $(\%)$ & 100 & 100 & 100 & 80 & 100 & 100 & 100 & 90 \\
\hline 3 & Sal (\%) & 32,5 & 33,0 & 33,0 & 33,5 & 32,3 & 34,0 & 34,0 & 34,0 \\
\hline 4 & Suhu $\left({ }^{\circ} \mathrm{C}\right)$ & 30,52 & 30,40 & 30,60 & 30,31 & 31,0 & 29,02 & 29,92 & 29,35 \\
\hline 5 & $\mathrm{pH}$ & 8,02 & 8,0 & 7,82 & 7,72 & 7,54 & 8,39 & 8,16 & 8,00 \\
\hline 6 & $\mathrm{DO}(\mathrm{ml} / \mathrm{L})$ & - & - & - & 4,12 & - & - & 4,49 & - \\
\hline
\end{tabular}

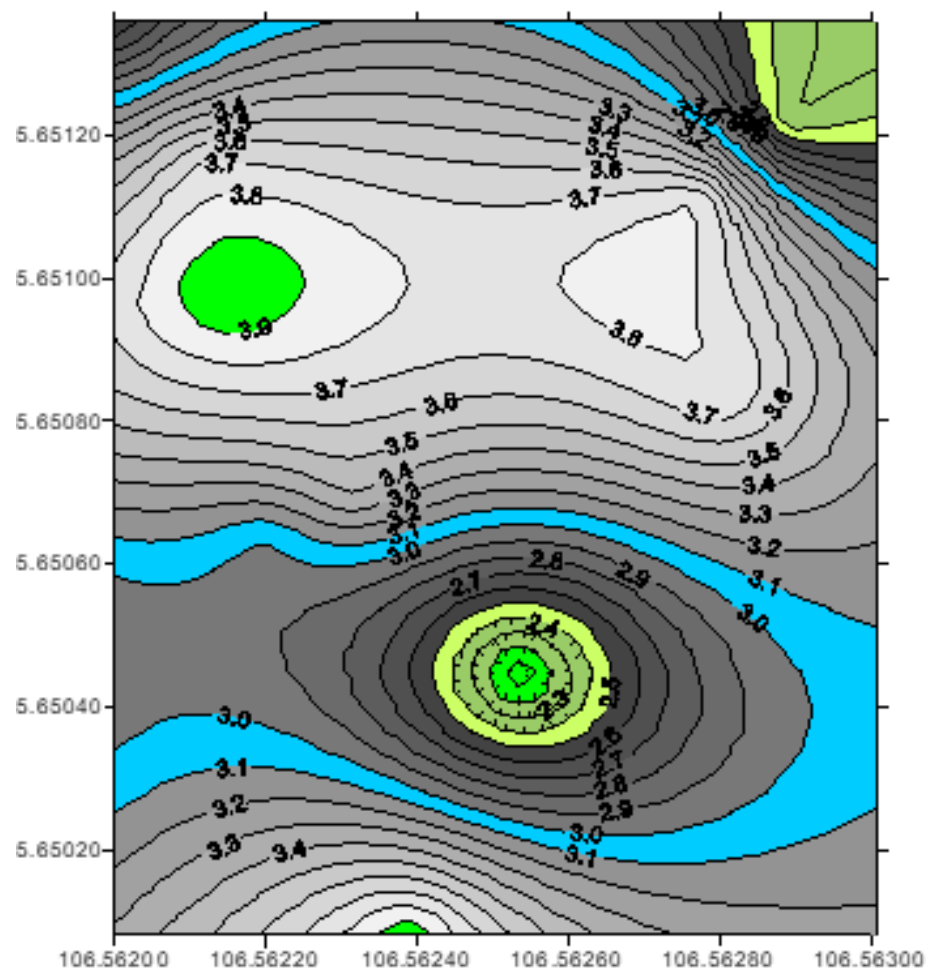

Gambar 8. Kontur dasar perairan di Pulau Pamegaran.
2004 menunjukkan bahwa kedalaman perairan berkisar antara 1- 4 m, kecerahan berkisar antara $80-100 \%$. Kadar salinitas berkisar antara 32.5 - 34.0 \%o. Suhu berkisar antara $29,02-31,0^{\circ} \mathrm{C}$, keasaman $(\mathrm{pH})$ berkisar antara 7,54 - 8,16. DO berkisar antara 4,12 - 4,49 ml/L (Tabel 6). Nilai nilai parameter lingkungan tersebut sesuai dengan habitat teripang secara alami, sehingga dapat dikatakan bahwa perairan Pulau Pamegaran dapat mendukung untuk kehidupan teripang (Martoyo et al, 1994). 
Tabel 7. Diameter partikel pasir di Pulau Pamegaran.

\begin{tabular}{|c|c|c|c|c|c|c|}
\hline Butiran $(\mu \mathrm{m})$ & Stasiun $1(\%)$ & Stasiun $2(\%)$ & Stasiun $3(\%)$ & Stasiun $4(\%)$ & Stasiun $5(\%)$ & Stasiun $6(\%)$ \\
\hline 1000 & 0 & 0 & 2 & 7 & 4 & 4 \\
\hline 600 & 10 & 2 & 6 & 3 & 10 & 6 \\
\hline 425 & 4 & 4 & 2 & 3 & 4 & 4 \\
\hline 212 & 8 & 6 & 4 & 9 & 10 & 8 \\
\hline 150 & 4 & 2 & 6 & 12 & 10 & 6 \\
\hline 90 & 8 & 52 & 10 & 64 & 12 & 10 \\
\hline 63 & 52 & 24 & 32 & 1 & 12 & 20 \\
\hline loose & 14 & 10 & 38 & 1 & 38 & 42 \\
\hline Total & 100 & 100 & 100 & 100 & 100 & 100 \\
\hline
\end{tabular}

penebaran teripang pasir merupakan perairan tertutup dengan kedalaman antara 1-4 m. Dengan kondisi perairan seperti yang disajikan pada Gambar 8 penyebaran teripang hanya terbatas di sekitar perairan tersebut.
Dasar perairannya terdiri dari pasir sangat halus dengan ukuran partikel yang dominan berkisar $63-90$ $\mu \mathrm{m}$ dengan persentase $32-64 \%$ (Tabel. 7. Teripang umumnya lebih menyukai substrat dasar perairan dengan ukuran partikel yang halus.

Tabel 8. Diameter partikel pasir di DPL Gosong Pramuka

\begin{tabular}{llll}
\hline Ukuran butiran $(\boldsymbol{\mu m})$ & \multicolumn{4}{l}{ Pramuka $\mathbf{1}(\%)$} & Pramuka $2(\%)$ & Pramuka 3 (\%) \\
\hline 1000 & 12 & 2 & 10 \\
600 & 18 & 14 & 22 \\
425 & 12 & 10 & 14 \\
212 & 26 & 40 & 20 \\
150 & 18 & 18 & 14 \\
90 & 10 & 14 & 2 \\
63 & 4 & 2 & 0 \\
loose & 0 & 0 & 100 \\
\hline Total & 100 & 100 & 10 \\
\hline
\end{tabular}

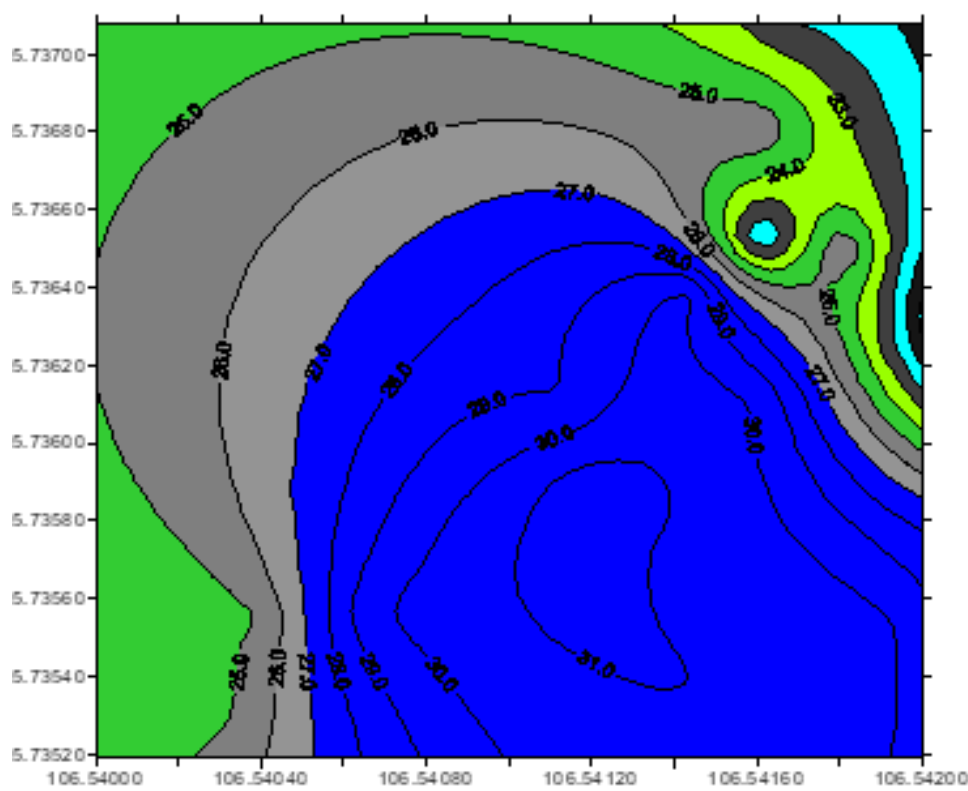

Gambar 9. Kontour dasar perairan Pulau Pramuka. 
Kondisi substrat dasar perairan di Gosong Pramuka relatif lebih kasar dari perairan Pulau Pamegaran, yaitu berkisar $150-212 \mu \mathrm{m}(14-40 \%)$ (Tabel 8). Lokasi penebaran Teripang di Pulau pramuka kondisi perairannya lebih terbuka sehingga memugkinkan penyebarannya lebih luas. Disekitar lokasi penebaran terdapat perairan yang kedalamannya mencapai $>25$ m (Gambar 9). Semakin bertambah besarnya teripang biasanya akan bermigrasi keperairan yang lebih dalam, sehingga teripang yang ditebar di perairan ini tidak dapat teramati semua.

\section{KESIMPULAN DAN SARAN}

Laju pertumbuhan teripang per hari pada beberapa kali percobaan pembesaran di Pulau Kongsi selama 8- 9 bulan pada kisaran 0,41-0,82\% dengan kelolos hidupan mencapai $100 \%$ dan Laju pertumbuahan per hari teripang yang dilepas di perairan Pulau Pamegaran selama 12 bulan adalah $0,4 \%$, dengan tingkat kelolos hidupan 4\%. Oleh karena itu, perairan Pulau Pamegaran merupakan lokasi yang tepat untuk kegiatan pelepasan (restocking) dan dapat dikembangkan sebagai daerah reservasi.

\section{UCAPAN TERIMA KASIH}

Tulisan ini dapat diselesaikan tepat pada waktunya oleh karena masing-masing penulis saling bersinergi untuk memberikan kontribusi sesuai dengan bidang ilmunya masing-masing dan selain itu oleh karena adanya bantuan secara teknis dari beberapa pihak terkait yang tak sempat disebut satu per satu, sehingga lewat kesempatan ini penulis memberikan apresiasi yang setinggi-tingginya serta ucapan terima kasih kepada para pihak tersebut.

\section{DAFTAR PUSTAKA}

Anonim. (2007). Ringkasan Hasil pertemuan COP 14 CITES dan Banggai Cardinal Fish. Direktorat Konservasi dan Taman Nasional Laut. Direktorat Jenderal Kelautan, Pesisir, dan Pulau-Pulau Kecil. Palu.

Darsono P. (2004). Teripang (Holothurians) perlu Dilindungi, Lokakarya Usulan Jenis Satwa dan Tumbuhan yang perlu Dilindungi Perundangundangan di Indonesia. Puslit Biologi-LIPI. Bogor, 8 Desember 2004. p.11.

Djamali A., Mubarak H., Mudjiono, Darsono P., Aziz
A., \& Sumadhiharga O.K. (1998). Sumber daya Moluska dan Teripang dalam Potensi dan Penyebaran Sumber Daya Ikan Laut di Perairan Indonesia. Kom.Nas. Pengkajian Stok Sumber Daya Ikan Laut: 156-163.

Eys S.V. (1986). The International Market for Sea Cucumber. INFO fish, 5, 41-44.

Hartati S.T., Basuki R., Dharmadi, \& Zainy R. (2000). Penelitian Bioekologi Teripang Pasir (Holothuria scabra) di perairan Kepulauan Seribu dalam Upaya Menunjang Kegiatan Pengkayaan Stok (Stock enhancement).

Hartati S.T., Wahyuni I.S., \& Zainy, R. (2001). Penelitian Stok Teripang dan Lingkungan Perairannya di Kep. Seribu. Lap.Keg.Pen. BPPL Jakarta.

Hashimoto Y. (1979). Marine Toxins and Other Bioactive Marine Metabolites. Japan Scientific. Press. Tokyo.

Martoyo, J.N. Aji., \& Winanto, T. (1994). Budidaya Teripang. Penebar Swadaya. Jakarta.

Nuraini, S., Subani, W., \& Wahyuni I.S. (1990). Studi Tentang Perikanan Teripang di Kab. Kolaka, Sulawesi Tenggara. Jur. Pen.Per.Laut. (54), 6571.

Smith, I.R., \& Marahudin F. (1985). *Eds). Ekonomi Perikanan; Dari Teori Ekonomi Pengelolaan Perikanan. Yayasan Obor Indonesia Gramedia. Jakarta.

Supriharyono. (2000). Pengelolaan Ekosistem Terumbu Karang. Penerbit Djambatan. Jakarta. p.118.

Teswara, A. (1995). Perbandingan Komposisi Jenisjenis Teripang (Holothuroidae) di P. Kayu Angin Bira dan P. Pramuka, Taman Nasional Laut P. Seribu Jakarta. Universitas Nasional. Jakarta. 